\title{
41. RELATIONSHIPS BETWEEN ACOUSTIC STRATIGRAPHY AND LITHOSTRATIGRAPHY IN THE WESTERN NORTH ATLANTIC BASIN ${ }^{1}$
}

\author{
Brian E. Tucholke, Lamont-Doherty Geological Observatory of Columbia University, Palisades, New York
}

\begin{abstract}
Detailed studies of seismic profiles and of correlations of reflectors to lithofacies at DSDP drill sites in the western North Atlantic show the following: "Horizon $A$ "' at various locations consists of one or more reflectors of a group, which is here termed the Horizon- $A$ complex. Four reflectors of the group are well defined, are consistently observed, and have specific lithologic correlations. The youngest is upper Oligocene Horizon $A^{V}$, which correlates with the top of a sequence of volcaniclastic turbidites recording weathering of Bermudan volcanics. Horizon $A^{V}$ is best defined within 200 $\mathrm{km}$ of Bermuda, and it merges laterally with the acoustically opaque Bermuda Pedestal. Horizon $A^{T}$ (middle to upper Eocene) marks the top of a sequence of siliceous turbidites that were deposited in the deep basin west of Bermuda until uplift formed the present Bermuda Rise. Horizon $A^{C}$ is upper lower to lower middle Eocene chert; it is developed within the turbidites west of Bermuda and in variable facies elsewhere in the basin. Horizon $A^{U}$ is an angular unconformity eroded by abyssal currents along the western margin of the basin after middle Eocene time. Horizon $A^{U}$ progressively truncates Horizon $A^{T}, A^{C}$, and older strata westward under the lower continental rise.

Horizon $A^{*}$ is a separate reflector normally found well below the Horizon- $A$ complex. It correlates with calcareous sediments a few meters to tens of meters thick that were deposited during a sharp depression of the carbonate compensation depth in late Maestrichtian time.

Horizon $\beta$ is the top of Neocomian limestones underlying Barremian/Cenomanian black clays. The reflector thus marks sharp changes in the oceanic circulation and the level of the CCD during the Early Cretaceous.

Horion $B$ underlies Horizon $\beta$ and is detected over a restricted lateral range in single-channel seismic profiles. This smooth, acoustic-basement reflector probably represents ponded highvelocity Upper Jurassic limestones that seismically mask the underlying basalt.
\end{abstract}

\section{INTRODUCTION}

\section{History of Acoustic Terminology}

The development of the seismic profiler for use in the deep sea (Ewing and Tirey, 1961) allowed simple correlation of reflecting horizons and provided a method of rapid, continuous display of sub-seafloor structure. Early profiler records (1961 through mid1964 ) collected by Lamont-Doherty Geological Observatory used explosives as a sound source and generally provided low resolution of individual seismic reflectors. However, certain reflectors of regional extent were observed within the sedimentary sections depicted in these early records. Ewing and Ewing (1963) dis-

\footnotetext{
${ }^{1}$ Lamont-Doherty Geological Observatory Contribution $\# 2514$.
}

cussed the sedimentary structure near several sites proposed for deep-sea drilling in the North Atlantic, and they recognized a widespread, relatively smooth horizon in the North American Basin and designated it reflector " $A$." Because of the smoothness and strong reflectivity of this horizon north of the Puerto Rico Trench, Ewing and Ewing (1962) suggested that the horizon consists of highly stratified sediments deposited from turbidity currents.

In studying the Argentine Basin sedimentary section, Ewing and Ewing (1965) and Ewing (1965) identified a smooth, acoustic-basement reflector (Horizon $B$ ) that occurs below "Horizon $A$ " and was observed intermittently between zones of irregular basement topography. Horizon $B$ was interpreted as a sediment surface representing an early stage of basin filling, the sediment having been deposited in the deepest depressions 
by turbidity currents. Horizon $A$ in the Argentine Basin again was interpreted as a fossil abyssal plain and was judged to have similar stratigraphic significance in all the Atlantic basins (Ewing and Ewing, 1965).

The development and routine use of a pneumatic sound source (Ewing and Zaunere, 1964) resulted in better resolution of reflecting horizons and more complete definition of the nature and occurrence of major reflectors. M. Ewing et al. (1966) identified Horizons $A^{\prime}$ and $B^{\prime}$ in the western Pacific by their acoustic signatures, which were similar to Horizons $A$ and $B$ in the Atlantic. On the Shatsky Rise in the Pacific they also named Horizon $\alpha$ (between $A^{\prime}$ and the seafloor) and Horizon $\beta$. Horizon $\beta$ marked the top of a sequence of acoustically laminated sediments lying between Horizons $A^{\prime}$ and $B^{\prime}$. Horizon $\beta$ and Horizon $B$ subsequently were named in the western North Atlantic, based on their stratigraphic position and acoustic signature (J. Ewing et al., 1966; Windisch et al., 1968).

The increased resolution provided by airgun profiler records also made it clear that Horizon $A$ in the Atlantic consists of a series of mostly parallel reflectors. This layering was interpreted by Ewing (1965) and Ewing and Ewing (1965) as further evidence for the turbidite nature of the Horizon $A$ sediments. In the North American Basin, Ewing and Hollister (1972) also distinguished Horizon $A^{*}$ as a reflector separate from and beneath Horizon $A$; near the basin margin these reflectors are often so closely spaced as to be nearly indistinguishable.

The evolution of reflector terminology in the North Atlantic, South Atlantic, and Pacific oceans has been based primarily on correlations of acoustic stratigraphy; that is, on the acoustic stratigraphic position and acoustic homotaxial nature of the reflectors. Thus there is no $a$ priori reason why the lithologic or age correlation of these reflectors should be the same from basin to basin or the same even within a single basin. Furthermore, the increased resolution of reflectors in airgun records and the expanding data base (which allows better cross correlation of reflectors in regional mapping) now make it clear that each of the closely spaced reflectors comprising a sequence such as "Horizon $A$ " could represent different depositional or diagenetic events of varying regional extent. These factors illustrate the need for precise regional mapping of reflectors and for unambiguous sampling of reflecting horizons. The historic development of this correlation of acoustics to lithology in the North American Basin is outlined below.

\section{Correlation of Reflectors With Lithology}

As early as Vema Cruise 18 in 1961, Horizon $A$ was observed to crop out near the Bahama Banks north of San Salvador, but the value of sampling the horizon was not recognized until subsequent profiler data showed that the reflector had regional significance. J. Ewing et al. (1966) and Saito et al. (1966) reported the results of piston cores taken in the outcrop area. Recovery of presumed turbidites of Maestrichtian age appeared to confirm early speculation, based on the smoothness and reflectivity of the reflector, that Horizon $A$ is a fossil abyssal plain.

With the advent of the Deep Sea Drilling Project in 1968, Horizon $A$ was targeted for drilling at several sites. In the western North Atlantic Ocean, Sites 6 through 10 were drilled into Horizon $A$ and all encountered lower to middle Eocene chert at the level of the reflective sequence (Ewing, Worzel, et al., 1969; Peterson, Edgar, et al., 1970; Ewing, et al., 1970). Generally fine-grained turbidites were found in the Eocene sediments at Sites 6-8, but it was clear that the strong impedance contrast responsible for the Horizon $A$ reflector was caused by the cherts, not by the turbidites. Ewing et al. (1970) recognized that the discrepancy in age and composition of Horizon $A$ beneath the Bermuda Rise and in the Bahama outcrop area was probably due to erosion or non-deposition along the base of the Bahama Banks.

Later drilling on DSDP Leg 11 penetrated Horizon $A$ at two locations beneath the eastern U.S. continental rise (Sites 101, 105) and at these locations the reflector matched an unconformity where 60-90 m.y. of Upper Cretaceous and lower Tertiary sediments are missing (Hollister, Ewing, et al., 1972). This information, coupled with the interpretation of Ewing et al. (1970) of erosion in the Horizon $A$ outcrop area, suggested that Horizon $A$ could represent a major unconformity eroded by early Tertiary bottom currents all along the western margin of the North American Basin.

A further interpretation of Horizon $A$ under the Greater Antilles Outer Ridge north of Puerto Rico was made by Tucholke and Ewing $(1974,1976)$. In this region, Horizon $A$ is the top of a highly reflective, smooth, and acoustically laminated sedimentary sequence; it was interpreted as silicified sediments near the top of a turbidite series that was being deposited until the end of middle Eocene time. A single piston core from a nearby Horizon- $A$ outcrop and spot cores at DSDP Site 28 on the outer ridge contain turbidites that support this interpretation.

Horizon $A^{*}$, lying below Horizon $A$, was first recognized as a reflector of regional significance by Ewing et al. (1970). This reflector is most widely separated from Horizon $A$ under the central Bermuda Rise; it approaches or merges with Horizon $A$ beneath the westernmost Bermuda Rise, and it probably diverges again below Horizon $A$ under the Hatteras Abyssal Plain. Prior to DSDP Leg 43, Horizon $A^{*}$ had been penetrated only at Site 105 on Leg 11. Drilling results there suggested that Horizon $A^{*}$ corresponded to the transition between undated multicolored clays and Lower Cretaceous black clays (Ewing and Hollister, 1972); however, a 48-meter interval was not cored near the level of the closely spaced Horizons $A$ and $A^{*}$ at Site 105 , and this lithologic correlation was uncertain.

Horizon $\beta$ was clearly identified and sampled by drilling at DSDP Sites 5, 101, and 105 (Ewing, Worzel, et al., 1969; Hollister, Ewing, et al., 1972). In these locations it correlates with the top of Neocomian limestones underlying Lower to middle Cretaceous 
black clays, and it ranges in age from Hauterivian to lower Barremian. At Sites 4, 99, and 100 in the Horizon $\beta$ outcrop area, Horizon $\beta$ is either not clearly defined or may be truncated by an unconformity near the level of the present seafloor. Sites 4 and 5 show variable carbonate contents within the "black-clay" sequence of the middle Cretaceous, and their relationships to Horizon $\beta$ are uncertain; the carbonates may originate from the local influence of the Bahama Banks on productivity patterns or from slumped bioclastic debris. Prior to DSDP Leg 43, the sites which had penetrated Horizon $\beta$ were all near the basin margin, and the question remained whether the limestone-black clay transition representing Horizon $\beta$ at Sites 5, 101, and 105 was also characteristic of $\beta$ away from the continental margin.

Because of the diverse or uncertain depositional processes, compositions, and ages indicated for the major acoustic Horizons $A, A^{*}$, and $\beta$, a program was instituted at Lamont-Doherty Geological Observatory for more precise definition, mapping, and correlation of reflectors within the North American Basin. Early phases of this study pinpointed areas where drill sites would be of maximum benefit in resolving the stratigraphic character of the reflecting horizons, and several of these sites were drilled on DSDP Legs 43 and 44. The summary that will be given in this paper is a stateof-the-art interpretation of the relationships between acoustic stratigraphy and lithostratigraphy in the western North Atlantic.

A compilation of lithofacies versus age for all DSDP boreholes in the North American Basin is presented in two color foldouts in the cover pocket of this volume (Figure 1), and the geologic correlation of major seismic reflectors is shown. The boreholes are arranged from left to right in a rough progression from south to north and from the continental margin toward the Mid-Atlantic Ridge. The first four boreholes at the left of Sheet 1 were all drilled in carbonate provinces on or near the continental margin. All data from DSDP Legs $1,2,4$, and 11 are taken directly from the Initial Reports. The precise age correlation of lithofacies dated on these earlier DSDP legs should be viewed with caution because of continuing revision and refinement of biostratigraphic scales during the course of the deep-sea drilling program.

\section{THE “HORIZON- $A$ ” COMPLEX}

Much of the uncertainty about why "Horizon $A$ ", has different lithologic correlations at different places stems from the fact that people often think of "Horizon $A$ " as a single reflector, whereas in reality "Horizon $A$ " is composed of one or more reflectors in a whole series of closely spaced reflectors. Of course, most of the individual reflectors in this series cannot be identified in early explosion profiler records or in lowfrequency ( 10 to approximately $50 \mathrm{~Hz}$ ) airgun records, because the long and complex signal obscures them.
However, in higher frequency records $(>50 \mathrm{~Hz}$ ), discrete reflectors often are observed, and several of the reflectors appear to have distinctly different lithologic correlations that were clarified by drilling on Leg 43.

Because of the multiple character of "Horizon $A$ " in the North American Basin, this reflector series is hereafter referred to as the Horizon- $A$ complex. Within the Horizon- $A$ complex, several reflectors, here called Horizons $A^{V}, A^{T}, A^{C}$, and $A^{U}$, appear to have systematic geologic correlations and regional significance. Although other reflectors are found in the complex, they tend to be weaker, have uncertain geologic meaning, or are only locally observed in available profiler data. The geologic correlations of Horizons $A^{V}, A^{T}$, $A^{C}$, and $A^{U}$, their interrelationships in the basin, and their significance in interpreting sedimentation patterns in the western North Atlantic are discussed below.

\section{Horizon $A^{V}$}

Horizon $A^{V}$ is the uppermost reflector in the Horizon- $A$ complex, and it is observed in seismic profiles recorded adjacent to Bermuda on the central Bermuda Rise (Figures 2 and 3). Site 386 is the only borehole that has penetrated Horizon $A^{V}$, and at this site the reflector clearly correlates with coarse, high-impedance, graded sands near the top of upper Eocene to upper Oligocene volcaniclastic turbidites derived from the Bermuda Pedestal (Figure 4).

The correlation of Horizon $A^{V}$ with the top of a volcaniclastic turbidite sequence is supported by the acoustic character and distribution of the reflector. Horizon $A^{V}$ is most reflective adjacent to the Bermuda Pedestal, and it merges smoothly with the acoustically impenetrable volcanic apron of the pedestal (Figure 3). Profiler data also show the reflector is restricted to the circum-Bermuda area (Figure 5).

Because of the strong reflectivity of Horizon $A^{V}$, it in places masks deeper reflectors in the Horizon- $A$ complex within $100 \mathrm{~km}$ of Bermuda. However, the reflector weakens and fades out in all directions from Bermuda. The declining reflectivity of Horizon $A^{V}$ away from Bermuda is attributed to a decrease in grain size and bed thickness of the Bermudan volcaniclastic turbidites.

Composition and textural characteristics of the volcaniclastic turbidites at Site 386 indicate that the Bermuda volcanic pedestal was eroded in a shallowwater or subaerial environment (Site 386 Report). Thus the pedestal was probably constructed up to sealevel by the end of middle Eocene time. Volcanism continuing into the middle Oligocene is indicated by $\sim 33 \mathrm{~m}$.y. radiometric ages of lamprophyric instrusive sheets beneath Bermuda (Reynolds and Aumento, 1974). A sharp cutoff in deposition of volcaniclastic turbidites in the late Oligocene is demonstrated both in the cores of Site 386 and by the crisp character of Horizon $A^{V}$ around Bermuda. The cutoff probably 


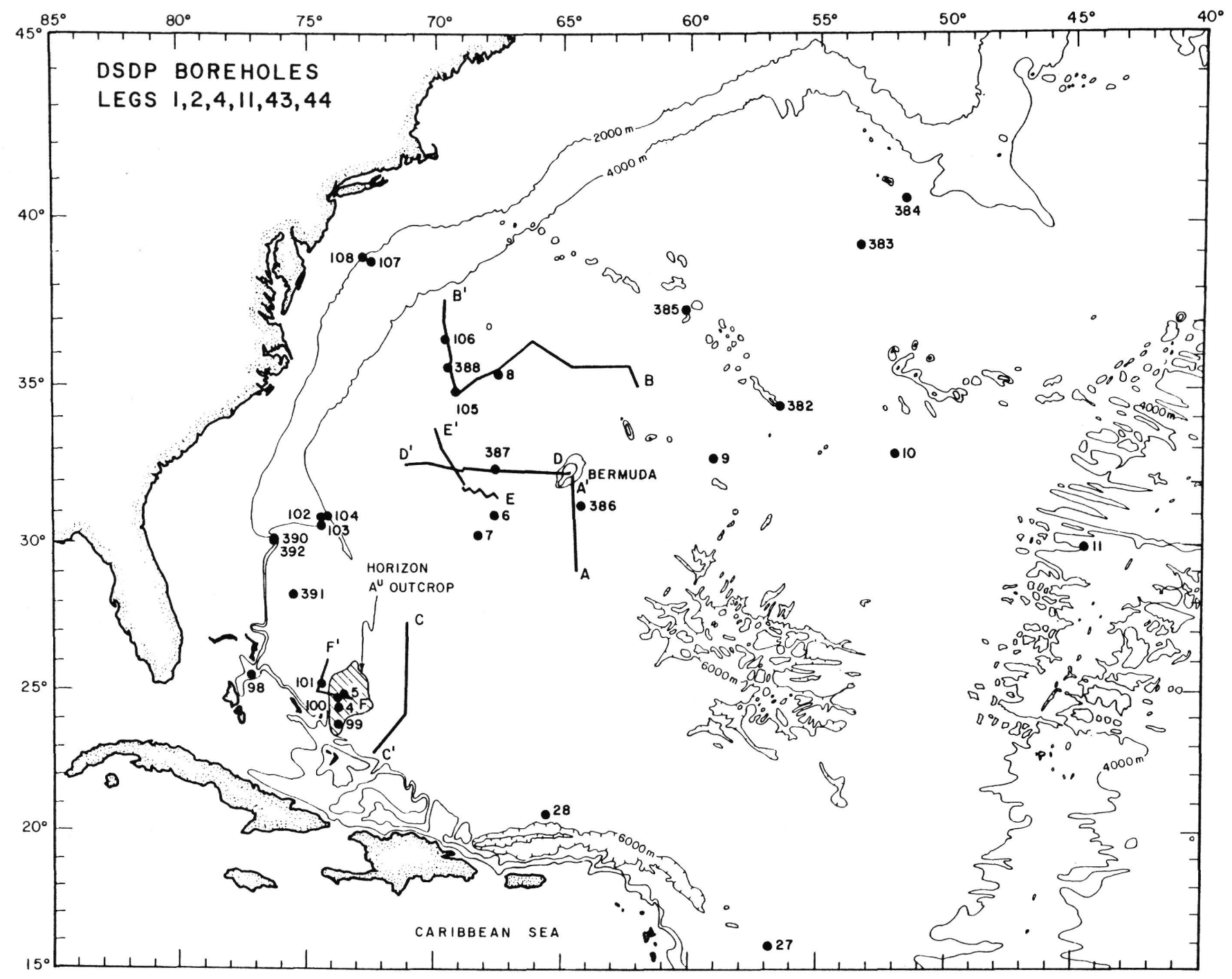

Figure 2. Locations of DSDP boreholes and seismic profiles illustrated in later figures. Contour interval 2000 meters.

resulted from erosion of the Bermudan volcanics to wave base, and it may have been accentuated by coeval cooling and subsidence of the pedestal.

\section{Horizon $\boldsymbol{A}^{T}$}

Where Horizon $A^{V}$ can be penetrated acoustically, a pair of reflectors appears about 0.15-0.2 seconds below $A^{V}$. In this pair, the upper reflector (Horizon $A^{T}$ ) usually overlies the lower (Horizon $A^{C}$ ) by about 0.05 0.2 seconds. The reflectors are widely distributed on the western Bermuda Rise, but Horizon $A^{T}$ has not been identified east of Bermuda. Other weaker and mostly discontinuous reflectors are commonly found between these two reflectors or below them.

Horizon $A^{T}$ has been penetrated at DSDP Sites 6, 7, 8,386 , and 387 , but core sampling was continuous enough to determine probable geologic correlation of the reflector only at Sites 386 and 387. At these two sites, Horizon $A^{T}$ corresponds to the top of an upper Paleocene to middle Eocene sequence of fine-grained siliceous turbidites (Figures 1, 4, and 6). At Site 6 farther south, Horizon $A^{T}$ overlies Horizon $A^{C}$ by about 0.06 to 0.08 seconds (nominally about 55 to 70 $\mathrm{m})$. Cores 3 and 4 taken within this interval contain middle-Eocene graded turbidites, but Core 2 taken above the interval has only uniform clays (Figure 1; Ewing, Worzel, et al., 1969). At Site 8 the Horizon $A^{T_{-}}$ $A^{C}$ separation is 0.1 seconds (nominally about $90 \mathrm{~m}$ ), and Core 2 within the interval contains upper-Eocene graded silty turbidites while Core 1 above the interval contains uniform clays (Petersen, Edgar, et al., 1970). No cores were obtained from the Horizon $A^{T}-A^{C}$ interval at Site 7. The turbidites at both Sites 6 and 8 contain abundant reworked calcareous and siliceous pelagic debris as well as terrigenous detritus. Thus all the available borehole data confirm that the Horizon $A^{T}-A^{C}$ interval contains turbidites with abundant pelagic biogenic components, and correlation at Sites $\mathbf{3 8 6}$ and 387 further indicates that Horizon $A^{T}$ marks the top of this turbidite sequence.

The widespread distribution of Horizon $A^{T}$ throughout the western Bermuda Rise demonstrates that the 


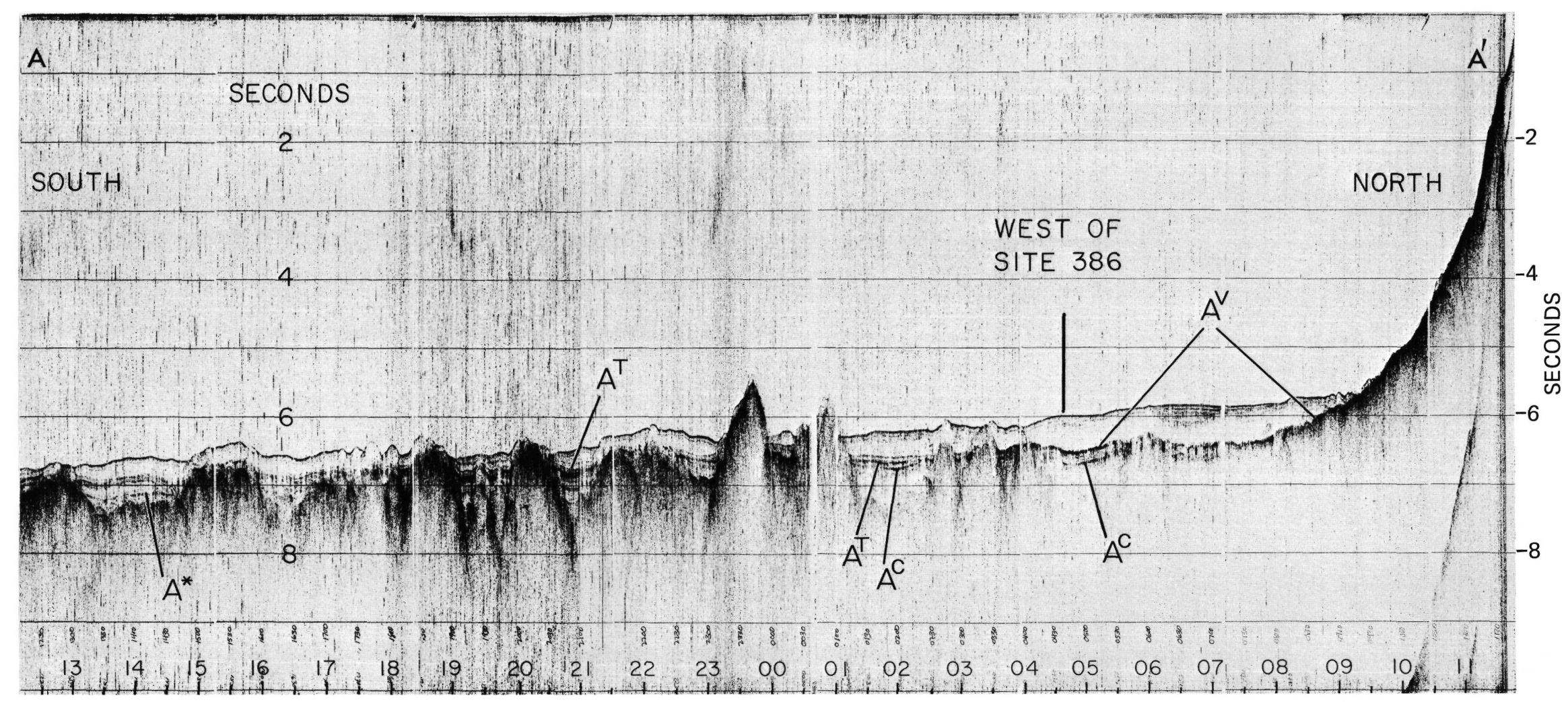

Figure 3. Vema 2306 seismic profile south of Bermuda. Note that Horizon $A^{V}$ merges with the acoustically opaque Bermuda Pedestal, and that it masks deeper reflectors near Bermuda. Location in Figure 2. 


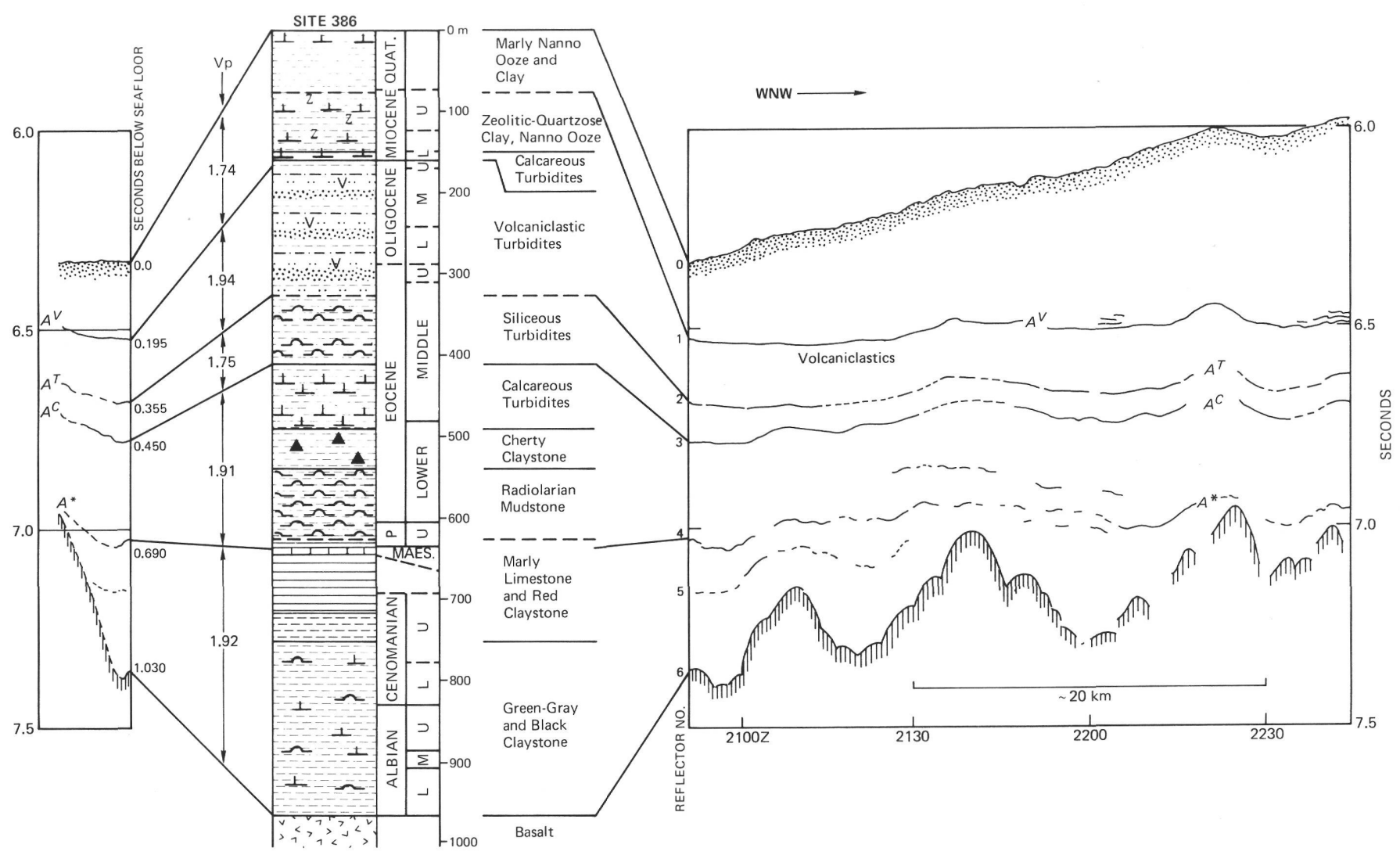

Figure 4. Correlation of reflectors and lithology at Site 386.

turbidites, despite their major biogenic component, are not the result of local sediment redistribution. The closest and most likely source is the continental margin of North America, the turbidites being deposited prior to the broad crustal uplift that formed the Bermuda Rise. The eastward limit of the turbidites on the northern Bermuda Rise is illustrated in Figure 7. Individual turbidite beds are several decimeters to more than a meter thick (see Site 386, 387 Reports; $\mathrm{McC}$ ave, this volume). Deposition of such thick turbidite beds so far from the probable source area and the presence of major biogenic components indicate that a substantial quantity of pelagic debris was incorporated in the turbidity currents along their path (Beall and Fischer, 1969).

An abrupt cutoff of turbidite deposition on the western Bermuda Rise is indicated both by the borehole results and by the acoustic nature of Horizon $A^{T}$. This appears to confirm the suggestion of Ewing et al. (1969) that the Bermuda Rise was formed late in the Eocene epoch, thus isolating the area from turbidite influx. Drilling results at Sites 386 and 387 show that uplift isolated these sites from turbidites by the end of the middle Eocene. Thus the uplift that formed the Bermuda Rise and the construction of the Bermuda volcanic pedestal appear to have occurred about the same time (see Horizon $A^{V}$ discussion).

Ewing et al. (1969) described the Bermuda Rise as an elliptical topographic rise, approximately centered on Bermuda, with a major, northeast-trending axis about $2000 \mathrm{~km}$ long and a minor axis about $1000 \mathrm{~km}$ long. As doming of the sea floor gradually formed the rise, the turbidites creating Horizon $A^{T}$ should have formed a sequence offlapping toward the west. There is some evidence for this presumed diachronous nature of Horizon $A^{T}$ in the DSDP boreholes, because the top of the turbidites appears to become younger toward the west. However, the uncertainties in the biostratigraphic ages make the validity of this observation questionable (see Sites 8, 387, 6, 386, in Figure 1).

Both the offlapping described above and the fact that the primary source area was probably the North American continental margin indicate that the thickness of the turbidite sequence below Horizon $A^{T}$ should increase toward the west. However, this simple picture has been complicated by extensive Paleogene erosion of the Eocene turbidites near and beneath the present continental rise. The effects of this erosion on reflector geometry and sediment distribution are discussed later under the section describing Horizon $A^{U}$.

\section{Horizon $A^{C}$}

As noted earlier, Horizon $A^{C}$ underlies Horizon $A^{T}$ by about $0.05-0.2$ seconds. Horizon $A^{C}$ usually is the strongest reflector in the Horizon- $A$ complex, and it is widely observed even where Horizon $A^{T}$ is absent, that is, over most of the Bermuda Rise and onto the lower flank of the Mid-Atlantic Ridge, beneath the Hatteras and Nares Abyssal plains and locally beneath the Sohm Abyssal Plain, and on the $J$-Anomaly Ridge 


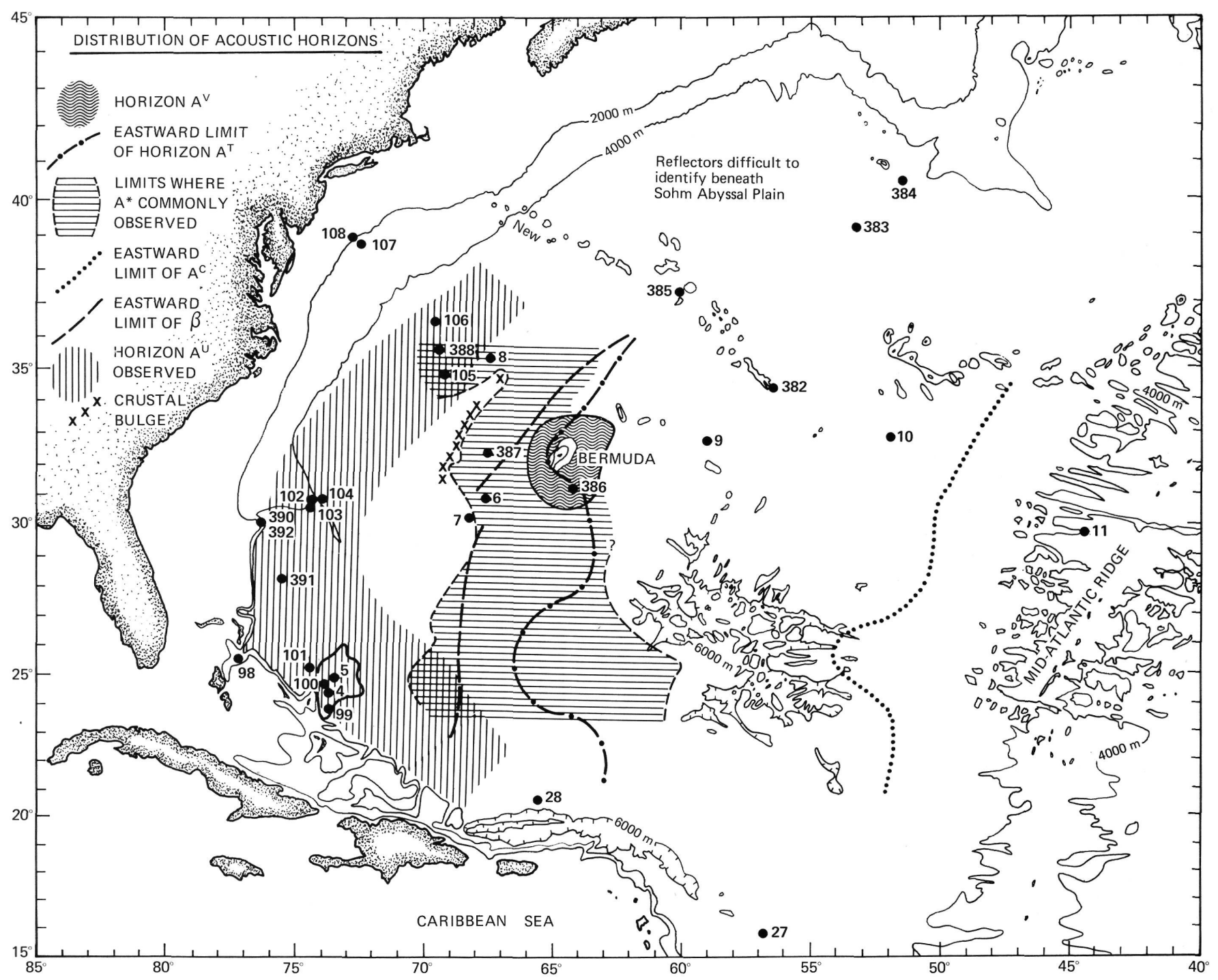

Figure 5. Approximate distribution of major acoustic horizons in the western North Atlantic, based on preliminary mapping from Lamont-Doherty seismic profiler records.

south of the Grand Banks (Figure 5; see Site 384 Report). East of Bermuda, however, the reflector usually occurs only in local patches in the variable sediment cover, and it is rarely continuous over large distances.

Horizon $A^{C}$ almost invariably correlates with upper lower to lower middle Eocene cherts at drill sites where it has been cored (Sites 6, 7, 8, 9, 10, 28, 384, 385, and 387; Figure 1), and it is therefore the seismic equivalent of what has commonly been referred to as "Horizon $A$ ", on the Bermuda Rise (Ewing et al., 1970). The strong reflectivity of Horizon $A^{\dot{C}}$ clearly results from the large impedance contrast created by cherts in the sedimentary section. One exception to the correlation of Horizon $A^{C}$ with chert is found at Site 386 , where the reflector matches the top of an 82-meter-thick sequence of calcareous turbidites overlying the lowermiddle Eocene cherts. Site 386 was drilled near the axis of a deep fracture valley, and the rapidly deposited turbidites which seismically mask the underlying cherts probably are sediments reworked from the adjacent bathymetric highs; a peak just $9 \mathrm{~km}$ south of Site 386 rises more than 1200 meters above the level of Horizon $A^{C}$ (see Bowles, this volume). Although reflectors including Horizon $A^{C}$ are difficult to discern below the highly reflective Horizon $A^{V}$ at Site 386, there is no obvious anomaly in the character or distribution of Horizon $A^{C}$ that suggests a "mismatch" with the cherty lithofacies. Thus Site 386 provides an example of potential disparities between acoustic and lithostratigraphic units, at least on a local scale.

In regions of the North American Basin where both Horizons $A^{T}$ and $A^{C}$ are found, the cherts that normally correlate with Horizon $A^{C}$ are developed within the sequence of Eocene siliceous turbidites (Sites 6, 7, $8,28,386,387)$. Beyond the limits of Horizon $A^{T}$, Horizon $A^{C}$ cherts occur within pelagic sediments containing siliceous debris (Sites 9, 10, 384, and 385). As Ewing et al. (1970) pointed out, the widespread extent of Horizon $A^{C}$ in a markedly siliceous sequence 


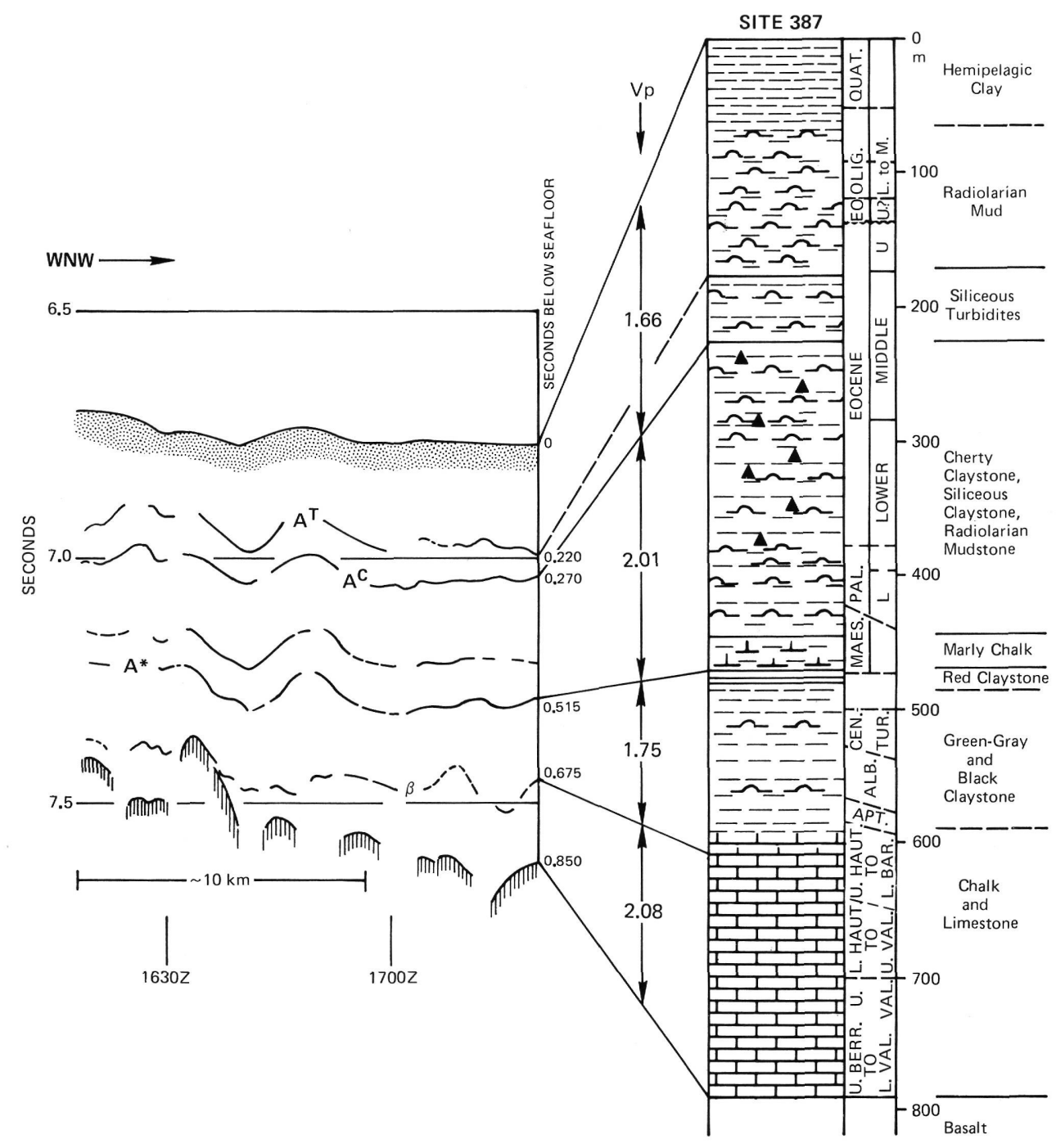

Figure 6. Correlation of reflectors and lithology at Site 387.

demonstrates that there was high productivity of siliceous organisms on at least a basin-wide scale during the Eocene. Although Horizon $A^{C}$ is not detected seismically in carbonate provinces along the basin margin, the event of siliceous productivity still is lithologically apparent on the Blake Nose at Site 390 (Benson, Sheridan, et al., 1976) and in the Old Bahama Channel at Site 98 (Hollister, Ewing, et al., 1972). Eocene cores recovered at these sites contain chert and siliceous fossils (Figure 1).

It is puzzling that the Horizon $A^{C}$ cherts are developed only over relatively short stratigraphic intervals within much thicker siliceous sequences. For example, at Site 387 the siliceous sediments are at least 286 meters thick but porcellanitic cherts are developed only below 134 meters depth in the siliceous sequence. At Site 386 the Eocene siliceous/calcareous sediments are more than 285 meters thick with cherts developed only in the upper part of the basal 125 meters.

The cherts are mostly of upper lower to lower middle Eocene age, irrespective of the character of the enclosing sediment. This restriction to a specific time- stratigraphic interval suggests that a basin-wide depositional event later affected chert diagenesis. A variety of such events has been suggested in the literature, including increased silica input to surface waters through volcanism (Gibson and Towe, 1971; Mattson and Pessagno, 1971), enhanced preservation of silica on the sea floor owing to high surface productivity coincident with submarine volcanic enrichment of silica in seawater (Herman, 1972), and increased productivity of siliceous organisms due to upwelling of nutrient-rich Arctic bottom water newly introduced into the basin (Berggren and Hollister, 1974). It is noteworthy that most of the lower to middle Eocene sediments associated with the cherts also tend to be enriched $(>20 \%)$ in carbonate (see Figure 1). Notable exceptions are found at Site 385 where a major unconformity overlies the chert, at Site 9 which was very sparsely cored, and at Site 8. At the deeper sites, the carbonate was introduced by turbidity currents (Sites 6, 7, 27, 28, 386, 387 ), and other sites were above the CCD (Sites 10, 384). Whether sediments at the carbonate-poor sites originally contained significant carbonate is unknown. 

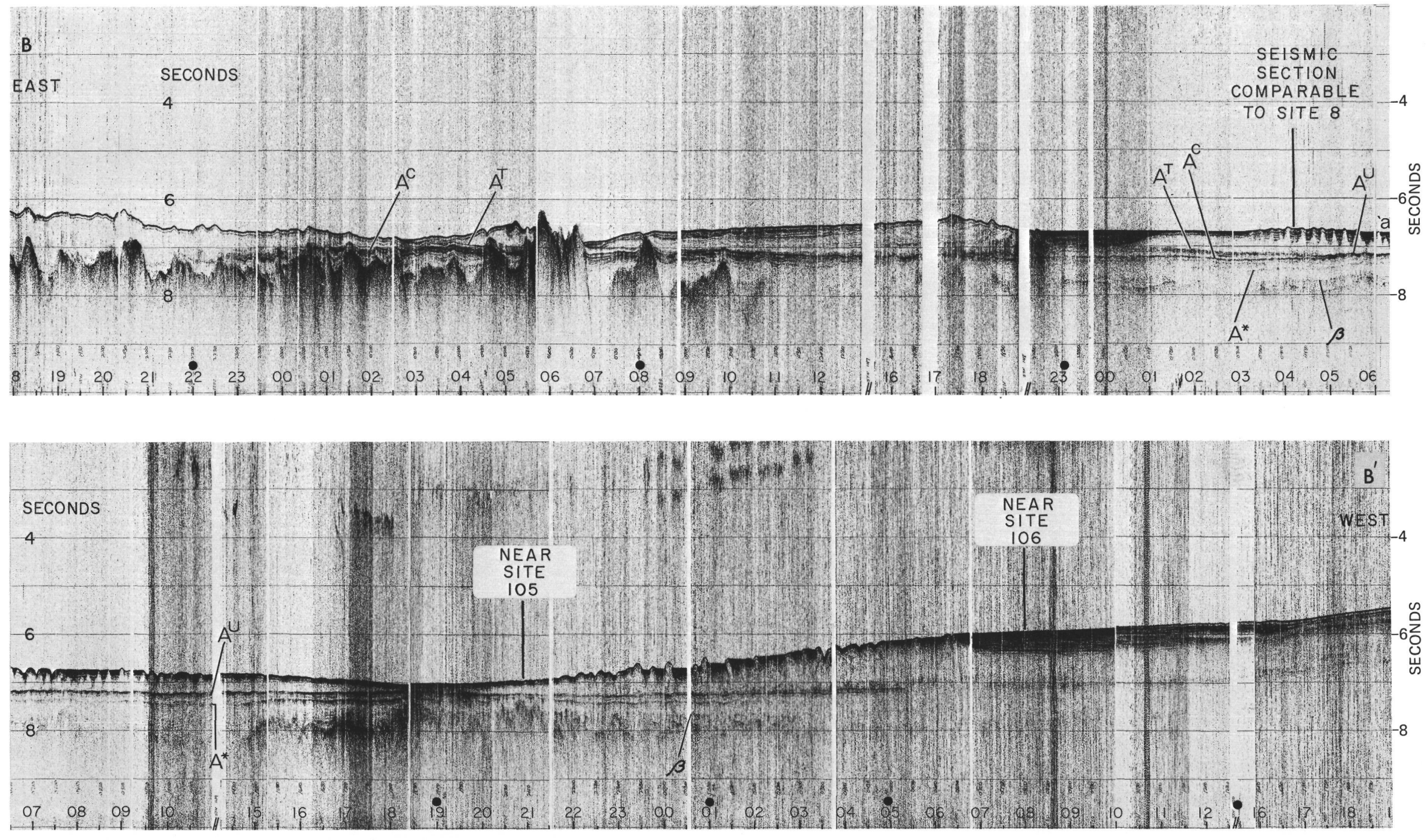

Figure 7. Vema 2307 seismic profile across the northern Bermuda Rise, lower continental rise hills, and lower continental rise (read from left to right, top to bottom). The angular unconformity represented by Horizon $A^{U}$ intersects Horizon $A^{T}$ near point " $a$ " and cuts into Horizon $A C$ about $40 \mathrm{~km}$ to the west. Note that the turbidite sequence which includes Horizon $A^{C}$ and is capped by Horizon $A^{T}$ fades out to the east. Location in Figure 2; black dots denote course changes. 
Riech and von Rad's studies of Leg 43 porcelanitic cherts (this volume) shows that the original carbonate content of cherty sediments at Site 387 may have been 2 to 3 times that presently observed; thus there is a possibility that the cherty sediments at Sites 8,9 , and 385 formerly contained carbonate. Because of the general co-occurrence of chert and calcareous sediments, it is tempting to associate the chertification process with the presence of the carbonates. Lancelot (1973) discussed mechanisms of chert formation in clayey and calcareous sediments and pointed out that the increased permeability of carbonate-rich sediments may be important in the mobilization and reprecipitation of biogenic silica to form chert. However, this does not explain the localization of cherts in sedimentary sections such as that at Site 384 , where a carbonate/ siliceous section is well developed for tens of meters above and below the chert. Thus, it is likely that an episode of very high productivity of siliceous microplankton in the late early Eocene to early middle Eocene, and subsequent diagenesis, may best explain the Horizon $A^{C}$ cherts.

\section{Horizon $\boldsymbol{A}^{U}$}

In seismic profiles recorded west and southwest of the Bermuda Rise near the margin of the basin, Horizon $A^{T}$ either becomes indistinct or appears to merge with Horizon $A^{C}$. In the vicinity of Sites 8 and 105 (Figure 1) these two horizons merge just west of Site 8 , and form a single reflector which can be traced to Site 105 (Figure 7). A major unconformity between probable Upper Cretaceous multicolored clays and upper Miocene hemipelagic clays was penetrated at Site 105; thus this single reflector is interpreted as an erosional unconformity and is termed Horizon $A^{U}$.

Horizon $A^{U}$ is clearly a diachronous reflector. In Figure 7 , the erosional surface is probably cut into ? Upper Cretaceous multicolored clays at Site 105; it presumably intersects the lower to middle Eocene cherts of Horizon $A^{C}$ near point "a," and it merges indistinguishably with the top of the upper Eocene turbidites representing Horizon $A^{T}$ east of Site 8 . Unfortunately, the core sampling was much too widely spaced at Site 8 to resolve whether or not an unconformity is present. At Site 105, if we assume continuous Paleocene to middle-Eocene sedimentation at rates at least as great at those observed at Site 387 on the Bermuda Rise, then a minimum of 200-300 meters of sediment were deposited and subsequently eroded at this location on the Eocene continental rise. Because Horizon $A^{U}$ cuts into progressively older sediments toward the west, the reflector can be considered an angular unconformity on a very broad scale (Figure 8 ). However, because the erosional surface is widespread, and because there are few reflectors below Horizon $A^{U}$, the horizon seldom is clearly defined as an angular unconformity in seismic profiles.

The westward limit of the Horizon $A^{U}$ erosional zone is not easy to define. At Site 106 there is some evidence that the deep, cherty cores recovered are Eocene (Horizon $A^{C}$ ?); therefore a major unconformity
(Horizon $A^{U}$ ) may be present in the section, above Horizon $A^{C}$ cherts (Figures 1, 7, and 8). Still farther west near the base of the continental slope, Site 108 cores recovered middle Eocene siliceous/calcareous sediment only 39-75 meters below the sea floor (Hollister, Ewing, et al., 1972). There is clearly an unconformity above the Eocene section at Site 108, but its cause, distribution, and relationship to Horizon $A^{U}$ are unknown.

The frequent lack of definition of Horizon $A^{U}$ as an angular unconformity makes it difficult to assess where the reflector represents an uncomformable surface. However, other clear cut examples of erosion occur beneath the Hatteras Abyssal Plain in the southwest part of the basin (Figure 9). Horizon $A^{U}$ also occurs at the sea floor or beneath a few meters of sediment in The Horizon $A$-Horizon $\beta$ outcrop area north of San Salvador (Figure 14; Ewing et al., 1966; Windisch et al., 1968). Within the Horizon Beta outcrop area, Horizon $A^{U}$ cuts into sediments at least as old as Barremian-Hauterivian (Windisch et al., 1968).

The agent that caused erosion of the Horizon $A^{U}$ unconformity is thought to be strong, abyssal thermohaline currents that developed when the North Atlantic was opened to sources of cold Arctic water (Ewing and Hollister, 1972; Berggren and Hollister, 1974). McKenna (1972) presented evidence that Greenland and Spitsbergen separated at the end of the early Eocene, thus providing a potential source of Arctic bottom water. However, the strong influx of bottom water necessary to erode sediments apparently was delayed at least until the late Eocene, as is demonstrated by relationships of the seismic reflectors in the western Atlantic basin. Horizon $A^{U}$ is observed cutting into Horizons $A^{C}$ and $A^{T}$, so erosion probably postdates the middle Eocene. Although it is possible that the continental margin was being eroded at the same time that the siliceous turbidites forming Horizons $A^{C}$ and $A^{T}$ were deposited, it is unlikely that these finegrained turbidites would have reached as far as the central Bermuda Rise if such a strong boundary current had been active across the path of the turbidity currents. The erosion also began before the diagenesis of upper lower to lower middle Eocene siliceous deposits formed the cherts of Horizon $A^{C}$, because bottom currents could not have eroded chertified sediments.

Drilling results at Site 101, 105, and 391 indicate that the deep boundary current remained strong enough to erode or prevent deposition along most of the continental rise until Miocene time (Hollister, Ewing, et al., 1972; Benson, Sheridan, et al., 1976). However, in the Horizon $A$-Horizon $\beta$ outcrop area the bottom currents have prevented all but negligible deposition up to the present.

\section{Horizon $A^{*}$}

Horizon $A^{*}$ was identified and named by Ewing and Hollister (1972) in the region of Site 105, but it is best developed on the western Bermuda Rise. Just west of Bermuda the reflector is interrupted by a series of ridges and seamounts, making it questionable whether 


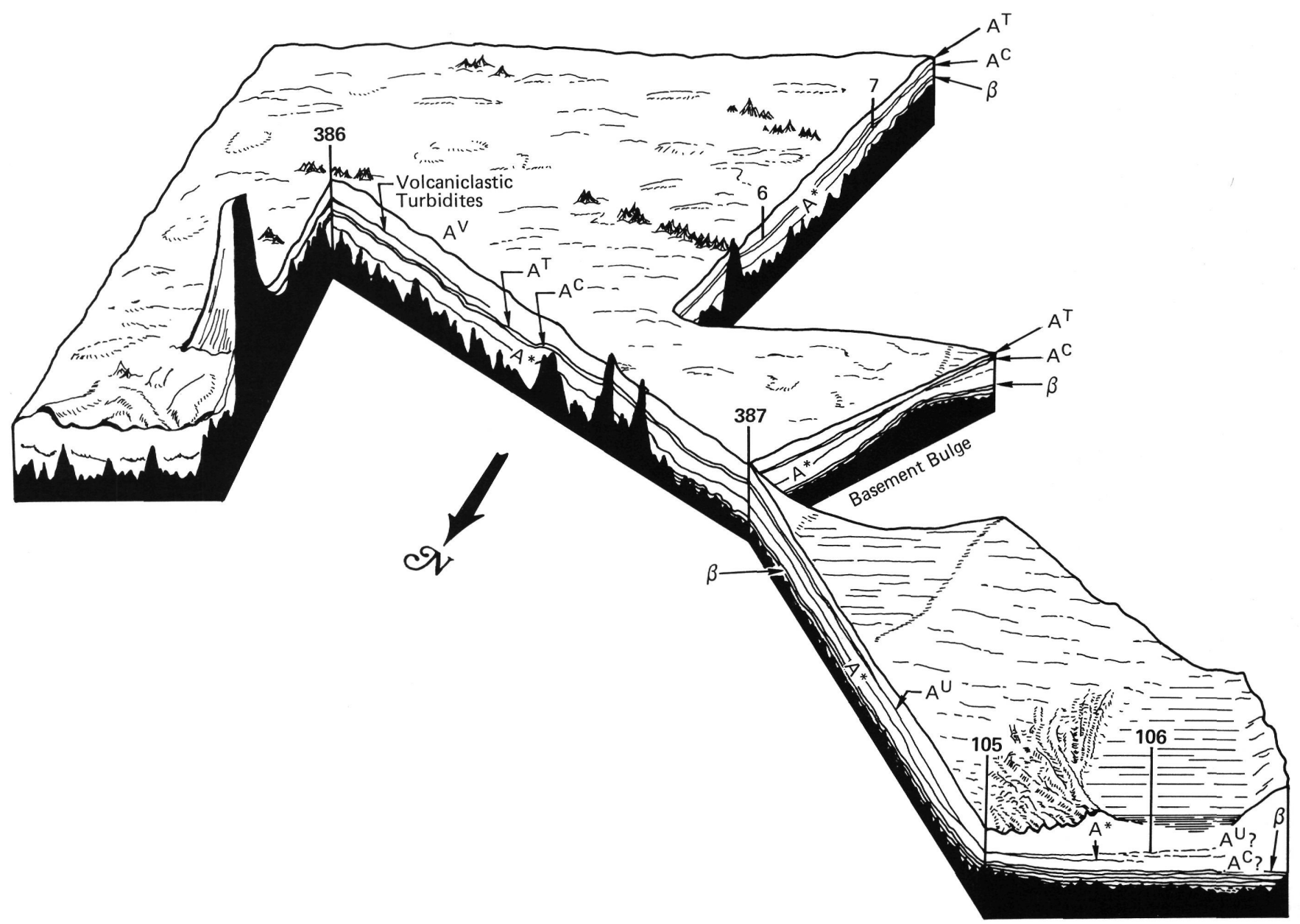

Figure 8. Schematic representation of reflector distribution in the western part of the North American Basin. Vertical scale variable.

the deep, strong reflector near Bermuda is the same as Horizon $A^{*}$ farther west (Figure 10). The Horizon $A^{C}$ to $A^{*}$ interval thins toward the west, and the two reflectors appear to merge above a broad basement bulge under the westernmost Bermuda Rise. West of the basement bulge, Horizon $A^{*}$ generally is a weak reflector, but it may again diverge beneath Horizon $A^{C}$. In the region of the lower continental rise hills at the north end of the Hatteras Abyssal Plain, Horizon $A^{*}$ converges only slightly with Horizons $A^{C}$ and $A^{U}$, except at Site 105 where $A^{U}$ and $A^{*}$ merge or are very closely spaced (Figure 7). Horizon $A^{*}$ has not been identified east of Bermuda, and its distribution north of Bermuda is presently unknown.

Because of the tentative correlation of Horizon $A^{*}$ to the transition between Cretaceous multicolored (volcanogenic?) clays and black clays at Site 105 (Ewing and Hollister, 1972), it was anticipated that a similar correlation would be found at Sites 386 and 387 and that the $A^{C}-A^{*}$ interval at these sites might consist of volcanogenic sediments. However, the drilling results indicate that Horizon $A^{*}$ correlates with an upper Maestrichtian limestone/chalk facies near the top of the multicolored clays at both sites (Figures 4 and 6 ) and that there is no well-defined reflector corresponding to the multicolored-clay to black-clay transition (see Site 386 and 387 Reports). The possible discrepancy with the Site 105 results could be a real difference, but it seems more likely that both Horizons $A^{U}$ and $A^{*}$ were penetrated in the 48 -meter uncored interval between Cores 4 and 5 at Site 105 (Figure 1). The separation of Horizons $A^{U}$ and $A^{*}$ at Site 105 is 0.05 second or less $(45 \mathrm{~m}$ at a nominal velocity of 1.8 $\mathrm{km} / \mathrm{sec}$ ), so that multicolored clays in Core 5 could have been recovered from below Horizon $A^{*}$.

Site 7 was drilled at a location where Horizons $A^{C}$ and $A^{*}$ merge and are seismically indistinguishable. Multicolored clays, presumably of Late Cretaceous age, were recovered in Cores 2 and 3 at Site 7, 42 meters below the cherts of Horizon $A^{C}$ (Figure 1); thus the multicolored clays at this site also appear to underlie Horizon $A^{*}$. At Site 8, a smear of bright red coloration over Recent sediment was observed on the outside of the drill collar at the time that the bottom hole assembly was recovered and the site abandoned (Peterson, Edgar, et al., 1970). Although drilling penetrated perhaps 10 meters beyond Horizon $A^{C}$ cherts at this site, no cores were recovered below Horizon $A^{C}$, and the level in the hole from which the reddish sediment originated is unknown. At Site 8, Horizon $A^{*}$ 


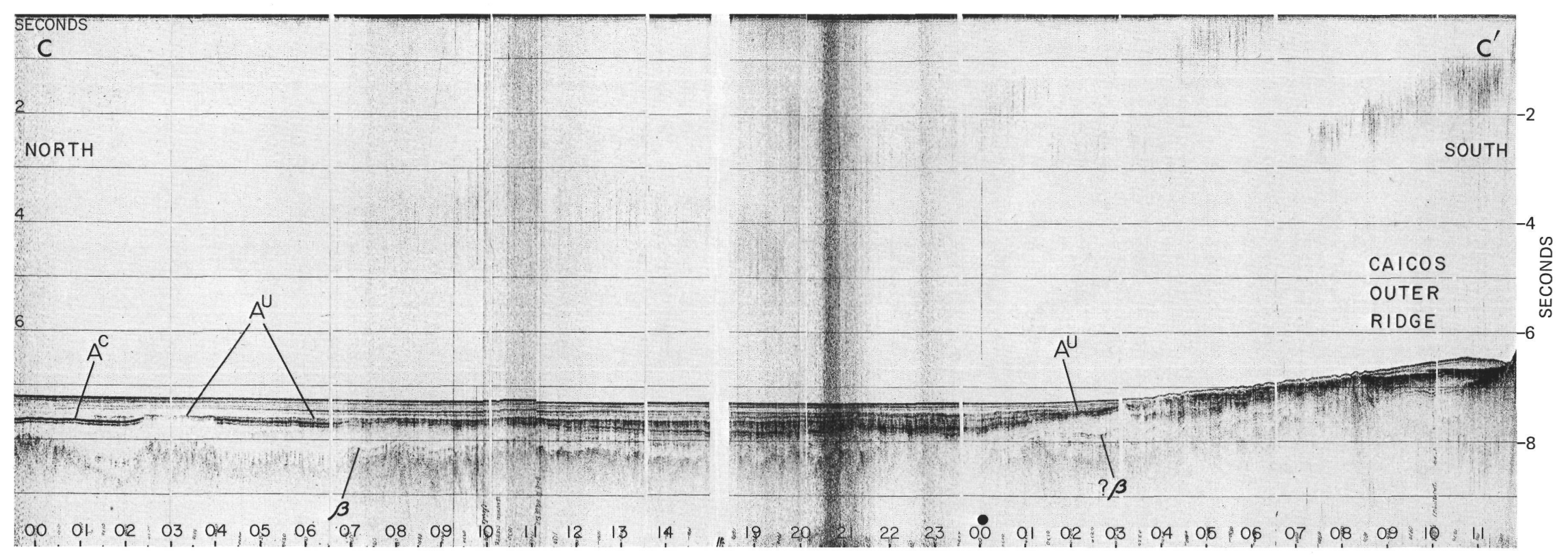

Figure 9. Vema 24 seismic profile across southern Hatteras Abyssal Plain and Caicos Outer Ridge (location in Figure 2). Note the erosional unconformity (Horizon $\left.A^{U}\right)$ which has truncated Horizon $A^{C}$. Black dot denotes course change. 

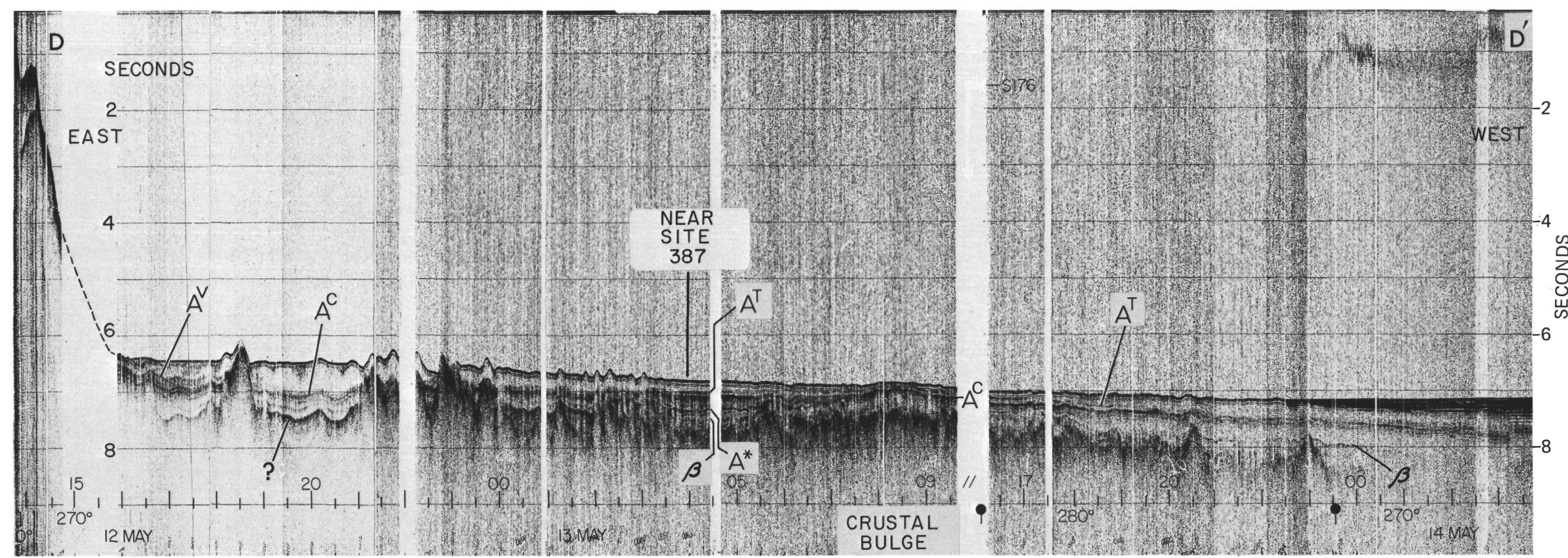

Figure 10. Vema 26 seismic profile west of Bermuda (location in Figure 2). Note that Horizon $A^{V}$ fades out toward the west. Horizon $A^{*}$ merges with Horizon $A^{C}$ above a prominent crustal bulge on the western Bermuda Rise, and it is not readily detected to the west. Black dots denote course changes. 
underlies Horizon $A^{C}$ by about 0.15 seconds $(135 \mathrm{~m}$ at a nominal velocity of $1.8 \mathrm{~km} / \mathrm{sec}$ ), and if the reddish sediment did come from between Horizons $A^{C}$ and $A^{*}$, then more than 125 meters of multicolored clays must overlie Horizon $A^{*}$ at this location, in addition to presumed similar clays below the reflector. The only site where multicolored clays definitely are known to occur above Horizon $A^{*}$ is Site 386 , where they are between 4 and 23 meters thick above the reflector and 85 meters thick below the reflector (Figure 1).

The correlation of Horizon $A^{*}$ to upper Maestrichtian limestones and chalks at Sites 386 and 387 has some interesting implications. Wherever middle to upper Maestrichtian sediments have been cored in the western North Atlantic (i.e., Sites 10, 384, 385, 386, 387 , and 390) they are highly calcareous, indicating a sharp drop in the level of the CCD during the latter part of the Maestrichtian (Figure 1; Tucholke and Vogt, this volume). Since Horizon $A^{*}$ correlates with this calcareous depositional pulse, its distribution and reflectivity may indicate the nature of the lithologic record in many parts of the basin. The relatively poor reflectivity of Horizon $A^{*}$ west of the Bermuda Rise could be caused by Maestrichtian deposition of thinner or less carbonate-rich calcareous sediments in this presumably deeper part of the basin. East of Bermuda, the poor development of Horizon $A^{*}$ may be due to the reflector's diminishing impedance contrast in the increasingly calcareous sedimentary record (refer to Site 10, Figure 1).

Where the Horizon $A^{*}-A^{C}$ interval was cored at Sites 386 and 387 , it corresponds to lower Eocene siliceous turbidites above a thin Paleocene pelagic sequence. The turbidites, like those extending upward to Horizon $A^{T}$, probably were derived from the North American continental margin, and they ponded in depressions and smoothed the sea floor (Figure 11). We expect the turbidite sequence to thicken westward toward the continental source, but as noted earlier, this kind of pattern is difficult to detect because of the Horizon $A^{U}$ unconformity and because of the difficulty in detecting Horizon $A^{*}$ under the Hatteras Abyssal Plain and continental rise. The turbidites also onlap Horizon $A^{*}$ where it crosses the basement bulge beneath the western Bermuda Rise (Figures 8 and 10); therefore, this crustal feature must predate the Eocene.

The seismic section just west of Bermuda between Horizon $A^{C}$ and the unidentified deep reflector is unusually thick if the deep reflector is actually Horizon $A^{*}$ (Figure 10). It is more reasonable that $A^{*}$ is the weaker, intermediate reflector in this profile, and that the $A^{C}-A^{*}$ thickness therefore is more uniform throughout the western Bermuda Rise. Unfortunately there are no profiler data to tie the deep seismic section just west of Bermuda directly to the reflectors (including $A^{*}$ ) that were drilled at Site 386.

If the deep reflector just west of Bermuda does predate Horizon $A^{*}$, it could record Late Cretaceous volcanism at Bermuda. This would explain the decreasing reflectivity of the reflector away from Bermuda, much the same as is observed for the Oligocene
Horizon $A^{V}$. There is little evidence for Late Cretaceous Bermudan volcanism, although Reynolds and Aumento (1974) reported extrusive lavas possibly of this age in the Bermuda drill core. In addition, abundant zeolites, probably derived from volcanic ashes, are found in the upper Cenomanian red clays at Sites 386 and 9 near Bermuda (Tucholke and Vogt, this volume).

\section{Horizon $\beta$}

Horizon $\beta$ is the reflector commonly marking the top of an acoustically laminated zone of sediments beneath Horizon $A^{*}$ (Figures 12 and 13; Ewing et al., 1966). Beneath the continental rise and Hatteras Abyssal Plain, the reflector generally is smooth, but under the western Bermuda Rise it drapes over the irregular basaltic basement. The eastern limit of Horizon $\beta$ roughly follows a north to northeast trending line west of Bermuda (Figure 5). Horizon $\beta$ has not been clearly identified north of the New England seamounts, although it may be present just north of Site 385 (see Site 385 Report). Within 70 to $100 \mathrm{~km}$ of the eastern limit where Horizon $\beta$ is identifiable in profiler records, the reflector becomes weak, intermittent, and difficult to detect, and it closely overlies basement. The acoustic lamination below Horizon $\beta$ also is poorly developed in this region.

Horizon $\beta$ has been drilled at five sites where profiler records suggest that there is a reasonably thick and continuous stratigraphic sequence above the reflector (Sites 5, 101, 105, 387, 391). At each of these sites, Horizon $\beta$ correlates with the downward transition from Cretaceous black clays to Hauterivian limestones (Figure 1; Hollister, Ewing, et al., 1972; Benson, Sheridan, et al., 1976). The contact between these lithofacies is often transitional, with interbedding of the two occurring over several meters to tens of meters. The impedance contrast creating Horizon $\beta$ is presumed to be the shallowest high-velocity calcareous sediment within the zone of interbedding. The limestones below Horizon $\beta$ commonly contain chert lenses and softer, marly interbeds (see, for example, Site 387 Report); the impedance contrasts between these interbedded lithofacies probably account for the acoustic lamination of sediments below Horizon $\beta$.

The age of Horizon $\beta$ varies over a range of some 6 to $8 \mathrm{~m}$.y. at these drill sites, from (?) Hauterivian at Sites 5 and 101 to about middle Barremian at Sites 387 and 391. However, the age of the reflector near the Bahama Banks may vary even more. Drilling at Site 4 in the Horizon $\beta$ outcrop area indicates the presence of substantial local accumulations of middle to Upper Cretaceous carbonate sediments; presumably Horizon $\beta$ seismically matches the top of this carbonate sequence and is Upper Cretaceous at Site 4. Possible causes of this persistent carbonate record include locally high surface productivity near the Bahamas, turbidites derived from the carbonate banks, and locally elevated sea floor. In addition, Horizon $\beta$ locally is observed in profiler records near the Bahama Banks as a possibly unconformable surface buried 


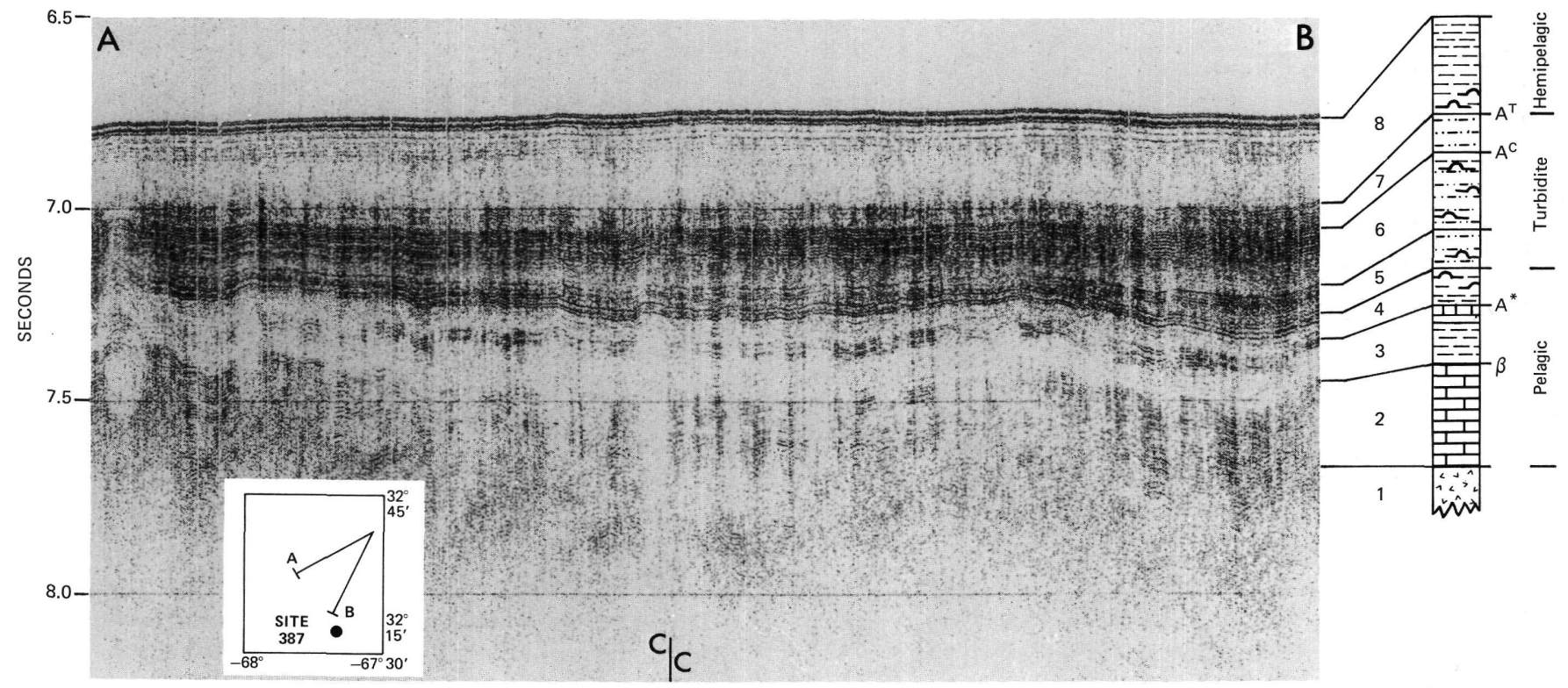

Figure 11. Challenger 43 seismic profile just north of Site 387 (inset shows location). Unit 1 is basalt. Pelagic, mostly conformable units are: 2-Neocomian limestones, 3-Barremian/Cenomanian black claystones and Upper Cretaceous multicolored clays capped by Maestrichtian carbonates, and 4-uppermost Maestrichtian and Paleocene clays and siliceous pelagic sediments. Turbidite infilling of depressions and smoothing of the seafloor was accomplished beginning in the late Paleocene or early Eocene; 5-siliceous turbidites clearly showing ponding, 6-siliceous turbidites capped by increasingly cherty sediments, 7-middle Eocene turbidites whose deposition was terminated (Horizon $A^{T}$ ) by uplift of this part of the Bermuda Rise (note smoothness of Eocene sea floor at this stage). Subsequent deposition of siliceous hemipelagic sediments and later clayey and calcareous sediments has characterized the late Paleogene and Neogene history of this part of the Bermuda Rise.

beneath several hundred meters of sediment (Figure 13). Whether this surface was created by erosion or by preferential deposition is not yet clear, but its age may be variable.

Sites 101, 105, and 387, which were drilled in locations not influenced by the Bahama Banks and Blake Plateau, show that Horizon $\beta$ is upper Hauterivian to middle Barremian, perhaps with carbonate deposition persisting longest on the shallower sea floor toward the east (Site 387, Figure 1). Although the last occurrence of carbonates at these sites may be diachronous, it is clear that the shoaling of the CCD near the end of the Hauterivian and the ensuing deposition of black clays was a geologically rapid event.

Horizon $\beta$ crops out in a seismically well defined area northeast of San Salvador, within the larger "Horizon- $A$ " outcrop area (Figures 5,14 ). The exposure of pre- $\beta$ sediments is caused by an erosional unconformity which correlates laterally with Horizon $A^{U}$. Piston cores taken near the perimeter of the outcrop area show that a few meters of Cenozoic (mostly Quaternary) sediment actually cover the outcrop (Windisch et al., 1968). Most of the cores also penetrated the Horizon $A^{U}$ unconformity and bottomed in sediments normally considered to postdate Horizon $\beta$ (Cenomanian gray and black clays, and younger Cretaceous sediments). If Horizon $\beta$ correlates with the top of calcareous sediments underlying the black clays, then the reflector does not crop out as shown in Figure 14 but in large part is covered by non- calcareous Cretaceous sediments too thin to be resolved in profiler data.

\section{Horizon $B$}

Horizon $B$ is a strong, relatively smooth reflector comprising acoustic basement in the Horizon $\beta$ outcrop area. The reflector generally cannot be traced far westward because the thicker sediments of the Bahama Outer Ridge and Blake-Bahama Basin prevent deep signal penetration. The smoothness of the reflector suggests that it is a sedimentary interface that closely overlies and masks basaltic basement (Ewing and Ewing, 1965).

Horizon $B$ has been penetrated only at Site 100 (Figure 1) where it correlates with the top of extrusive basalt (Hollister, Ewing, et al., 1972). However, Site 100 was drilled within six kilometers of a probably basaltic basement ridge, and Horizon $B$ also shows local irregularity at the site. Thus a local correlation of Horizon $B$ to basalt is not unexpected, and there is still a strong possibility that the bulk of Horizon $B$ is sedimentary in nature. Multichannel seismic profiles recently acquired farther landward along the continental margin of the United States are able to resolve reflectors at and below the stratigraphic level of Horizon $B$. Although these reflectors have not been correlated to lithofacies by deep drilling, there is no doubt that they are sedimentary, and they progressively onlap basaltic basement away from the continental margin. Horizon $B$ is probably the most seaward extension of 


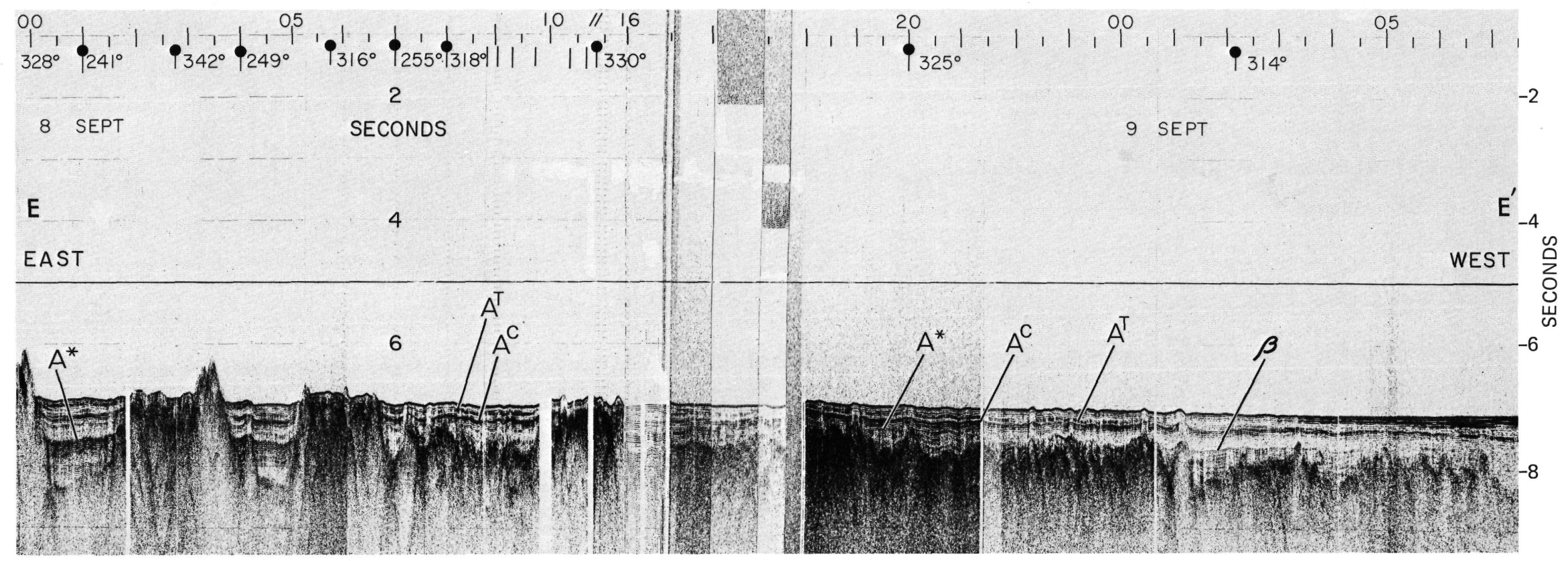

Figure 12. Conrad 16 seismic profile over the western Bermuda Rise (location in Figure 2). Note that Horizon $\beta$ is the top of an acoustically laminated sequence which thins and disappears toward the east. Black dot: denote course changes. 


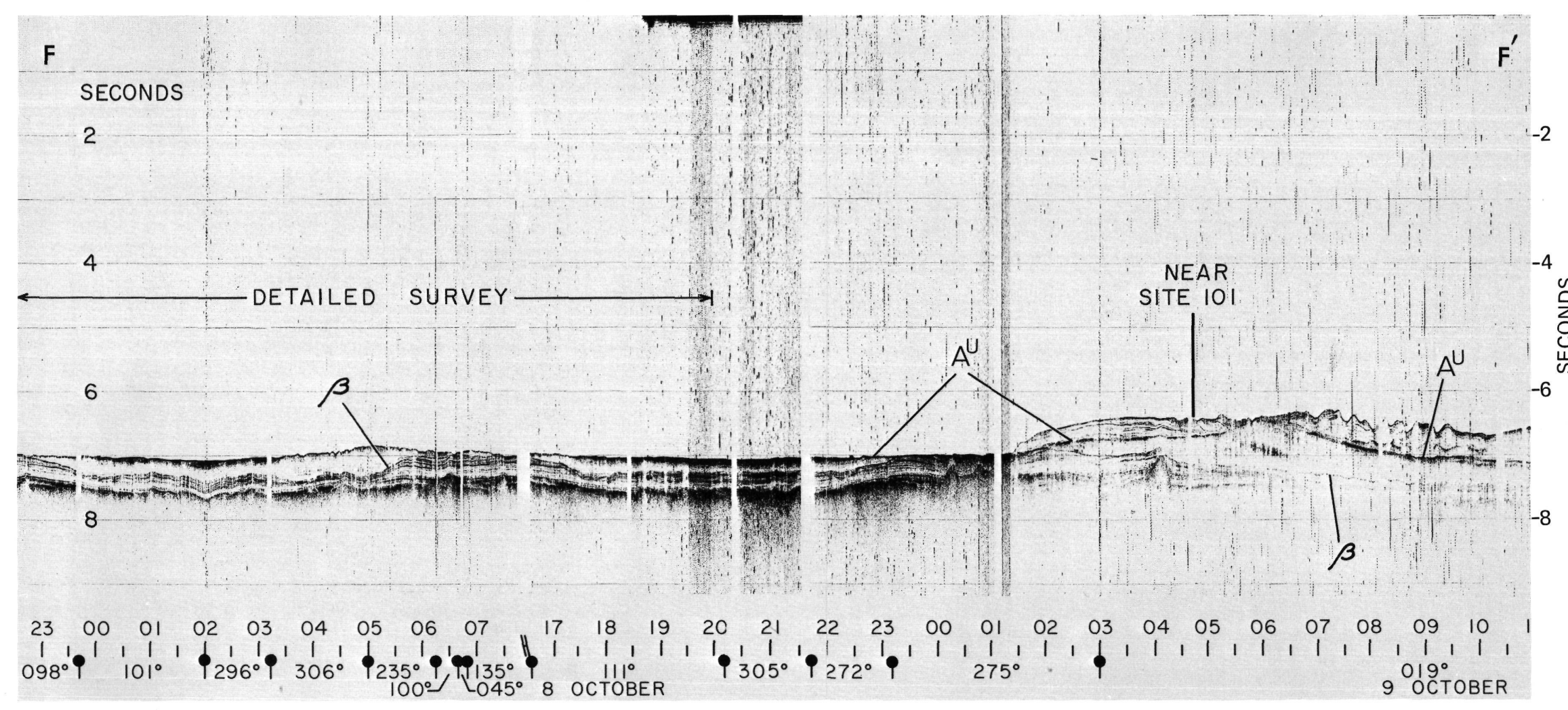

Figure 13. Conrad 10 seismic profile over and northwest of the Horizon A-Horizon $\beta$ outcrop area (location in Figure 2). Numerous course changes (black dots) on the left half of the profile are not shown in Figure 2. Note that Horizon $\beta$ appears to be an unconformable surface showing preferential erosion or deposition. Also note that Horizon $A^{U}$ forms the seafloor in the outcrop area at the left. Horizon $A^{U}$ corresponds to a 90-m.y. hiatus at Site 101. 


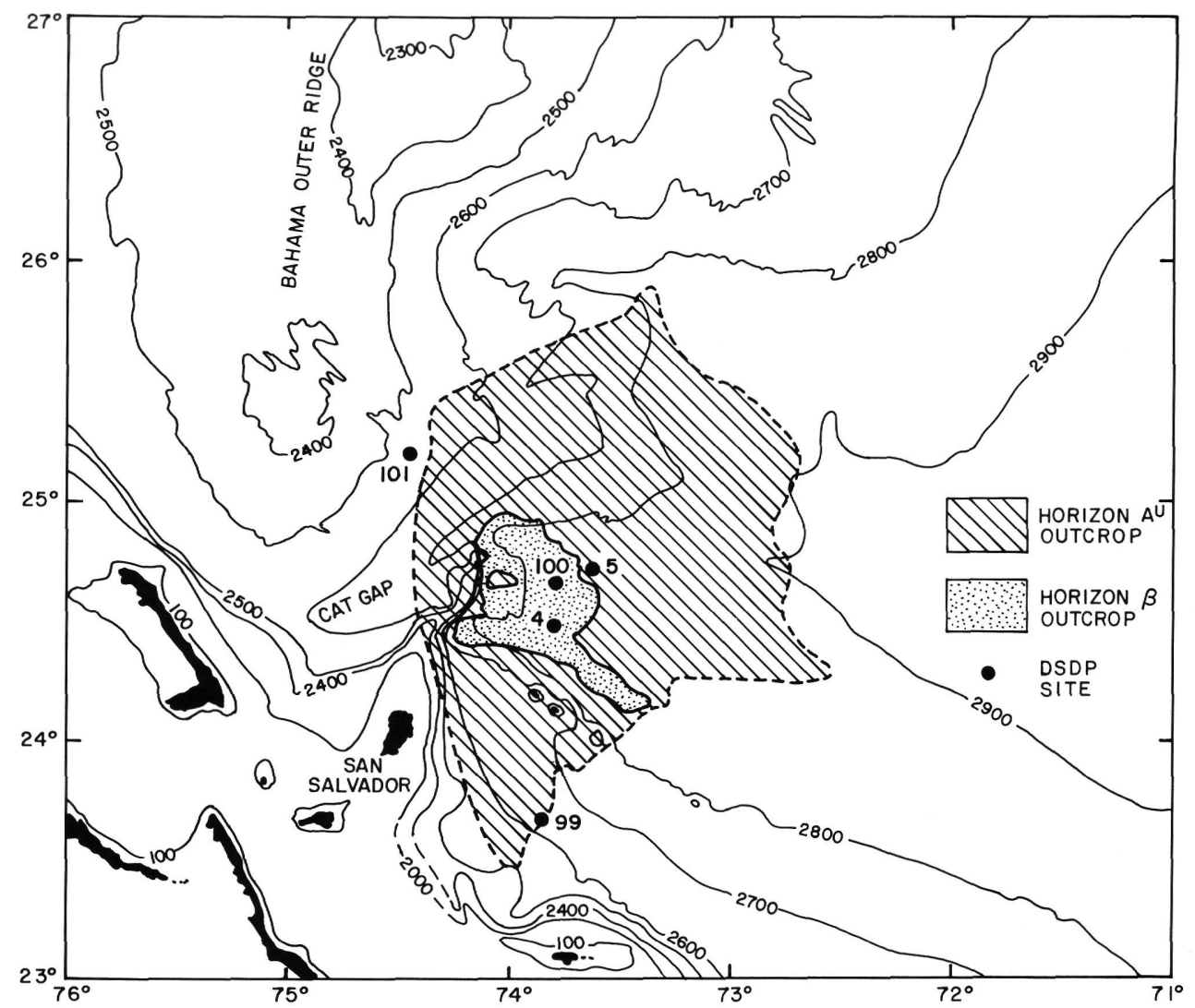

Figure 14. Outcrop areas of Horizon $A^{U}$ and Horizon $\beta$ (after J. Ewing et al., 1966, and Windisch et al., 1968). DSDP site locations are shown.

one of these sedimentary layers, possibly limestone that is ponded over and masks the basaltic basement.

\section{SUMMARY AND CONCLUSIONS}

A seismic reflector represents a physical (impedance) contrast within the sediment column and consequently it need not retain the same lithologic or age correlation over its entire lateral range. This is especially apparent when the reflector represents an unconformable surface or a diagenetic horizon where diagenesis is dependent upon depth of burial.

On the other hand, at the low frequencies commonly used for seismic profiling $(10-200 \mathrm{~Hz})$, the strong impedance (density $\times$ velocity) contrasts required to produce a reflector mostly are created by sharp lithologic changes, because density and velocity are dependent on sediment texture and composition. If we assume for the moment that a reflector can represent a consistent lithologic boundary, there is still a possibility of significant age variation for the reflector. For example, the age of a reflector representing the top of a carbonate sequence is subject to lateral variation due to factors such as shifts in productivity patterns or changes in depth of the CCD where the sea floor is of nonuniform depth.

Considering these cautionary notes, the major reflecting horizons in the North American Basin show remarkably consistent geologic and age correlations where they have been sampled. The kinds of lithologic and age variations that could be expected mostly fall close to the limits of resolution of borehole/reflector correlation and biostratigraphic time scales. Thus the reflectors can be considered to represent geologically rapid changes in the depositional framework of the basin.

Horizon $\beta$ has been drilled at locations where the crustal ages range from upper Berriasian/lower Valanginian (Site 387) to probably Middle or Lower Jurassic (Site 391). In each case where a correlation can be made between the lithologic and seismic record, the horizon marks the top of limestones or lithified chalks underlying black clays, and it is of Hauterivian to Barremian age. Thus Horizon $\beta$ seismically marks the onset of stagnation of Atlantic deep water, the Early Cretaceous rise of the CCD, and the initial major deposition of the Atlantic black clays. The Hauterivian/Barremian age of the reflector is in reasonable agreement with the age indicated by the seaward pinchout of Horizon $\beta$ (Figure 5), according to the geomagnetically determined crustal ages of Pitman and Talwani (1972).

Horizon $A^{*}$ correlates with a layer of middle to upper Maestrichtian calcareous sediments. At Site 386 the layer is near the top of the Upper Cretaceous multicolored clays, and at Site 387 it is interbedded between the low-carbonate multicolored clays and Paleocene siliceous clays. Provided the reflector has the same lithologic correlation at Site 105 , Horizon $A^{*}$ was 
probably penetrated at that site without being cored. Because of its correlation to a carbonate layer, Horizon $A^{*}$ may become seismically indistinct in the ridge-flank carbonate province east of Bermuda. There appears to be no reflector of regional significance between Horizons $\beta$ and $A^{*}$ beginning probably late in the Cretaceous black clays and overlying multicolored clays.

Fine-grained siliceous turbidites were deposited above Horizon $A^{*}$ beginning probably late in the Paleocene and continuing to the end of the middle Eocene on the western Bermuda Rise. Horizon $A^{T}$ correlates with the top of this turbidite sequence and marks the final deposition of turbidites as crustal uplift formed the Bermuda Rise. In the region west of Bermuda, Horizon $A^{C}$ lies below Horizon $A^{T}$ and correlates with porcellanitic cherts developed within upper lower to lower middle Eocene turbidites. Horizon $A^{C}$ persists eastward beyond the limits of Horizon $A^{T}$, where it also correlates with cherts of the same age but within different lithofacies. One feature common to upper lower and lower middle Eocene sediments at most drill sites is that they are silica rich and of higher carbonate content than adjacent sediments in the lithologic column. This compositional change was presumably caused by very high surface productivity and enhanced silica preservation on the sea floor; subsequent diagenesis of these sediments formed the Horizon $A^{C}$ cherts.

After the deposition of Horizon $A^{T}$ near the end of the middle Eocene, strong bottom-current erosion removed several hundred meters of the sedimentary section in the region of the present lower continental rise. The angular unconformity created by this erosion (Horizon $A^{U}$ ) cuts through Horizons $A^{T}$ and $A^{C}$, and probably into Mesozoic sediments in places under the present continental rise and Blake Bahama Outer Ridge. The very low angle at which Horizon $A^{U}$ intersects deeper reflectors often makes it difficult to identify the angular unconformity.

Horizon $A^{V}$ overlies Horizon $A^{T}$ in the region immediately surrounding Bermuda, and it correlates with coarse-graded sands near the top of a sequence of volcaniclastic turbidites. The turbidites date from the late Eocene to late Oligocene, and they were derived from weathering of the Bermuda volcanic pedestal. Horizon $A^{V}$ fades out away from Bermuda, probably because of finer grain size in the more distal turbidites, and the reflector distribution shows the limits of turbidite dispersal.

As was stated at the onset of this paper, this is a state-of-the-art summary of seismic interpretation and correlations of reflectors and lithology in the North American Basin. When better reflector definition in seismic records becomes possible (particularly in multichannel reflection), when more continuous coring is conducted in DSDP boreholes, and when better crosscorrelation between seismic profiles is achieved, these interpretations will be improved or modified. However, it is clear that with sufficient lithostratigraphic control at DSDP drill sites, acoustic stratigraphic interpretation is an extremely valuable tool in determining sedimentation patterns in the deep sea.

\section{ACKNOWLEDGMENTS}

I thank my shipboard colleagues for their excellent efforts in making Leg 43 a success and for stimulating discussions about North Atlantic acoustic stratigraphy and lithostratigraphy. I also am indebted to R. A. Sheridan, W. E. Benson, and the scientific staff of DSDP Leg 44 for permission to incorporate Leg 44 borehole data (Sites 388, 390, 391, and Hole 392A) in the color foldouts at the back of this volume. The manuscript benefited from critical reviews by J. I. Ewing, C. D. Hollister, and C. C. Windisch.

Special thanks are extended to the Office of Naval Research (Contract N00014-75-C-0210) and the National Science Foundation (Grant GA 27284) for long continued support of the Lamont-Doherty marine-seismology program, which has acquired more than a million kilometers of profiler data in the North Atlantic Ocean. This data library has been invaluable in selection of JOIDES borehole locations, and it has made possible the extensive tracing and cross correlation of reflectors that is essential to meaningful geologic interpretation of seismic records. Funds specifically for the interpretation and analysis of western North Atlantic borehole and seismic data were provided by the Oceanography Section of the National Science Foundation, Grant OCE-76-02038.

\section{REFERENCES}

Beall, A. O., Jr. and Fischer, A. G., 1969. Sedimentology. In Ewing, M., Worzel, J., et al., Initial Reports of the Deep Sea Drilling Project, v. 1: Washington (U.S. Government Printing Office), p. 521-593.

Benson, W. E., Sheridan, R. E., Enos, P., Freeman, T., Gradstein, F., Murdmaa, I. O., Pastouret, L., Schmidt, R. R., Stuermer, D. H., Weaver, F. M., and Worstell, P., 1976. In the North Atlantic: Deep Sea Drilling, Geotimes v. 21 , p. 23-26.

Berggren, W. A. and Hollister, C. D., 1974. Paleogeography, paleobiogeography and the history of circulation in the Atlantic Ocean. In Hay, W. W. (Ed.), Studies in Paleoceanography: Soc. Econ. Pal. Min. Spec. Publ. 20, p. 126-186.

Ewing, J. I. and Ewing, M., 1962. Reflection profiling in and around the Puerto Rico Trench, J. Geophys. Res., v. 67, p. 4729-4739.

Ewing, J. I. and Hollister, C. D., 1972. Regional aspects of deep-sea drilling in the western North Atlantic. In Hollister, C. D., Ewing, J. I., et al., Initial Reports of the Deep Sea Drilling Project, v. 11: Washington (U.S. Government Printing Office), p. 951-973.

Ewing, J. I. and Tirey, G. B., 1961. Seismic profiler, J. Geophys. Res., v. 66, p. 2917-2927.

Ewing, J. and Zaunere, R., 1964. Seismic profiling with a pneumatic sound source, J. Geophys. Res., v. 69, p. 49134915.

Ewing, J., Windisch, C., and Ewing, M., 1970. Correlation of Horizon A with JOIDES borehole results, J. Geophys. Res., v. 75, p. 5645-5653.

Ewing, J. I., Worzel, J. L., Ewing, M., and Windisch, C., 1966. Ages of Horizon A and the oldest Atlantic sediments, Science, v. 154, p. 1125-1132.

Ewing, M., 1965. The sediments of the Argentine Basin, Quart. J. Roy. Astr. Soc., v. 6, p. 10-27.

Ewing, M. and Ewing, J., 1963. Sediments at proposed LOCO drilling sites, J. Geophys. Res., v. 68, p. 251-256. 
1965. The sediments of the Argentine Basin, $A n$. Brasilian Acad. Sci., v. 37 (supplement), p. 1-61.

Ewing, M., Saito, T., Ewing, J. I., and Burckle, L. H., 1966. Lower Cretaceous sediments from the northwest Pacific, Science, v. 152, p. 751-755.

Ewing, M., Worzel, J. L., et al., 1969. Initial Reports of the Deep Sea Drilling Project, v. 1: Washington (U.S. Government Printing Office).

Ewing, M., Worzel, J. L., and Burk, C. A., 1969. Regional aspects of deep-water drilling in the Gulf of Mexico, east of the Bahama Platform and on the Bermuda Rise. In Ewing, M., Worzel, J., et al., Initial Reports of the Deep Sea Drilling Project, v. 1: Washington (U.S. Government Printing Office), p. 624-640.

Gibson, T. G. and Towe, K. M., 1971. Eocene volcanism and the origin of Horizon A, Science, v. 172, p. 152-154.

Herman, Y., 1972. Origin of deep-sea cherts in the North Atlantic, Nature, v. 238, p. 392-393.

Hollister, C. D., Ewing, J. I., et al., 1972. Initial Reports of the Deep Sea Drilling Project, v. 11: Washington (U.S. Government Printing Office).

Lancelot, Y., 1973. Chert and silica diagenesis in sediments from the Central Pacific. In Winterer, E. L., Ewing, J. I., et al., Initial Reports of the Deep Sea Drilling Project, v. 17: Washington (U.S. Government Printing Office), p. 377-405.

Mattson, P. H. and Pessagno, E. A., Jr., 1971. Caribbean Eocene volcanism and the extent of the Horizon A, Science, v. 174 , p. $138-139$.
McKenna, M. C., 1972. Eocene final separation of the Eurasian and Greenland-North American landmasses, 24th Internat. Geol. Congr., Sec. 7, p. 275-281.

Peterson, M. N. A., Edgar, N. T., et al., 1970. Initial Reports of the Deep Sea Drilling Project, v. 2: Washington (U.S. Government Printing Office).

Pitman, W. C. III, and Talwani, M., 1972. Sea-floor spreading in the North Atlantic, Geol. Soc. Am. Bull., v. 83, p. 619-646.

Reynolds, P. H. and Aumento, F., 1974, Deep Drill 1972. Potassium-argon dating of the Bermuda drill core, Canadian J. Earth Sci., v. 11, p. 1269-1273.

Saito, T., Burckle, L. H., and Ewing, M., 1966. Lithology and paleontology of the reflective layer Horizon A, Science, v. 154 , p. 1173-1176.

Tucholke, B. E. and Ewing, J. I., 1974. Bathymetry and sediment geometry of the Greater Antilles Outer Ridge and vicinity, Geol. Soc. Am. Bull., v. 85, p. 1789-1802. 1976, Bathymetry and sediment geometry of the Greater Antilles Outer Ridge and vicinity: Reply, Geol. Soc. Am. Bull., v. 87, p. 1371-1374.

Uchupi, E., 1971. Bathymetric atlas of the Atlantic, Caribbean, and Gulf of Mexico, Woods Hole Oceanogr. Inst. Ref. No. 71-72 (unpublished manuscript).

Windisch, C. C., Leyden, R. J., Worzel, J. L., Saito, T., and Ewing, J., 1968. Investigation of Horizon Beta, Science, v. 162 , p. $1473-1479$. 